\title{
Evaluation of a Webquest on the Theme "Management of Material Resources in Nursing" by Undergraduate Students
}

\author{
Marta Cristiane Alves Pereira ${ }^{1}$ \\ Márcia Regina Antonietto da Costa Melo ${ }^{1}$ \\ Adriana Serafim Bispo e Silva² \\ Yolanda Dora Martinez Évora ${ }^{3}$
}

\begin{abstract}
The learning process mediated by information and communication technology has considerable importance in the current context. This study describes the evaluation of a WebQuest on the theme "Management of Material Resources in Nursing". It was developed in three stages: Stage 1 consisted of its pedagogical aspect, that is, elaboration and definition of content; Stage 2 involved the organization of content, inclusion of images and completion; Stage 3 corresponded to its availability to students. Results confirm the importance of information technology and information as instruments for a mediating teaching practice in the integration between valid knowledge and the complex and dynamic reality of health services. As a result of the students' favorable evaluation of the approximation with the reality of nursing work and satisfaction for performing the activity successfully, the WebQuest method was considered valid and innovating for the teaching-learning process.
\end{abstract}

Descriptors: Nursing Informatics; Education, Nursing; Educational Technology.

\footnotetext{
${ }^{1}$ RN, Ph.D. in Nursing, Professor, Escola de Enfermagem de Ribeirão Preto, Universidade de São Paulo, WHO Collaborating Centre for Nursing Research Development, SP, Brazil. E-mail: Marta - martacris@eerp.usp.br, Márcia - mracmelo@eerp.usp.br.

${ }^{2}$ RN, Ph.D. in Nursing, Professor, Faculdade de Educação São Luis de Jaboticabal, SP, Brazil. E-mail: bispoadriana@uol.com.br.

${ }^{3}$ RN, Ph.D. in Nursing, Full Professor, Escola de Enfermagem de Ribeirão Preto, Universidade de São Paulo, WHO Collaborating Centre for Nursing Research Development, SP, Brazil. E-mail: yolanda@eerp.usp.br.
}

Corresponding Author:

Marta Cristiane Alves Pereira

Universidade de São Paulo. Escola de Enfermagem de Ribeirão Preto.

Departamento de Enfermagem Geral e Especializada.

Av. Bandeirantes, 3900

Bairro Monte Alegre

CEP: 14040-902 Ribeirão Preto, SP, Brasi

E-mail: martacris@eerp.usp.br 


\title{
Avaliação da WebQuest gerenciamento de recursos materiais em enfermagem por alunos do curso de graduação
}

O processo de aprender, mediado pelas tecnologias da informação e comunicação, assume enorme importância no contexto atual. O objetivo deste estudo foi descrever a avaliação de um WebQuest, na temática "gerenciamento de recursos materiais em enfermagem". Foi desenvolvido em três etapas: a Etapa 1 consistiu no aspecto pedagógico de elaboração e definição do conteúdo, a Etapa 2 envolveu organização do conteúdo, inclusão de imagens e conclusão do acabamento e a Etapa 3 correspondeu à disponibilização aos alunos. Os resultados confirmaram a importância das tecnologias da informática e informação como instrumento para a prática docente mediadora, na integração entre conhecimentos válidos e realidade complexa e dinâmica dos serviços de saúde. A avaliação dos alunos foi favorável para a aproximação à realidade do trabalho dos enfermeiros e a satisfação pelo cumprimento da atividade com sucesso, permitiram considerar a metodologia WebQuest como válida e inovadora para o processo ensino/ aprendizagem.

Descritores: Informática em Enfermagem; Educação em Enfermagem; Tecnologia Educacional.

\section{Evaluación de la WebQuest administración de recursos materiales en enfermería por alumnos del curso de graduación}

\begin{abstract}
El proceso de aprender mediado por las tecnologías de la información y comunicación asume enorme importancia en el contexto actual. El objetivo de este estudio fue describir la evaluación de una WebQuest, en la temática "administración de recursos materiales en enfermería"; fue desarrollado en tres etapas: la Etapa 1 consistió en el aspecto pedagógico de elaboración y definición del contenido; la Etapa 2 envolvió la organización del contenido, inclusión de imágenes y conclusión del acabamiento y la Etapa 3, correspondió a la disponibilización a los alumnos. Los resultados confirmaron la importancia de las tecnologías de la informática e información como instrumentos para la práctica docente mediadora en la integración entre conocimientos válidos y realidad compleja y dinámica de los servicios de salud. La evaluación de los alumnos fue favorable para la aproximación a la realidad del trabajo de los enfermeros y la satisfacción por el cumplimiento de la actividad con éxito, lo que permitió considerar la metodología WebQuest como válida e innovadora para el proceso enseñanza-aprendizaje.
\end{abstract}

Descriptores: Informática Aplicada a la Enfermería; Educación en Enfermería; Tecnología Educacional.

\section{Introduction}

Teaching, especially in the final year of Nursing undergraduate programs, can be considered a challenge to deal with the difficulties to make students apply theoretical knowledge to solve the complex problems experienced in daily health service situations. In this perspective, the learning process mediated by information and communication technologies gains considerable importance in the current context.
The WebQuest concept was developed in 1995 by Bernie Dodge, a professor at the University of San Diego in California, USA, as a methodological proposal to direct the good use of internet for information, research and development of activities that are guided by a teacher, require superior thinking living, are not restricted to summaries but include critical sense, synthesis, analysis, problem solving and creativity ${ }^{(1)}$. 
The WebQuest activity is like a mission to accomplish, involving students in the development of a project that should go beyond classroom space and time. The main characteristic of the project should be authenticity, in the sense of true and real, instead of being abstract, artificial and academic. It is a task someone needs to do in real life. Its presentation can be simple, but the content quality of the work is fundamental(2).

In general, the teacher elaborates a WebQuest for the students to solve in groups. It departs from a theme and proposes a task that involves consulting information sources the teachers has especially selected, also called resources, which can be books, videos and even people to interview, but they are normally websites ${ }^{(3)}$.

The teacher's construction of a WebQuest involves a range of activities that include the construction of fundamental phases or steps: 1) Introduction; 2) Task; 3) Process; 4) Assessment; 5) Conclusion; 6) Credits $^{(2-3)}$

Assessment is considered a primary component of WebQuest. It should be clearly presented how the task result will be evaluated and what criteria will be considered. The criteria should be clearly established according to the objectives. Assessment through rubrics is indicated for application in WebQuests ${ }^{(2)}$. Those are considered particularly useful assessment instruments to address complex and subjective evaluation criteria, as they are conducted by assessment methods that correspond as closely as possible to daily life experience. Rubrics were initially developed in arts and professional training, in which learning verification has always been performance-based ${ }^{(4)}$.

Rubrics are guided aimed at scoring the student's performance on the sum of a complex set of criteria instead of one single numerical score. In general, the rubric is presented to the students before the start of activities, with a view to making them think on the criteria based on which their work will be assessed(5).

In this type of assessment, the students themselves get involved in the assessment process, allowing them to administer their learning and eliminating the frontier between teaching, learning and assessment. The rubric is considered a type of formative assessment, which intends to simulate a real-life activity in which the students are engaged in solving concrete problems ${ }^{(4)}$.

Different forms of rubrics can be created with different complexity levels, but any rubric should contain the following characteristic: a) focus on measurement of the established goal (performance, behavior or quality); b) use a classification reference to situate performance; c) establish specific performance characteristics, organized in levels that indicate the extent to which a certain standard is achieved ${ }^{(4)}$.

Education is alternative when it is productive, permits the student to re-elaborate the information, experience and apply, recreate possibilities and even invent, produce and express knowledge, involving an intense production process allied with significant efforts, that is, which makes sense for the student and is also inserted in a general sense of the entire learning process $^{(6)}$.

In this perspective, this study explores the possibilities of the WebQuest method as an educational technology that favors teaching, research and practice integration in the search to qualify health work and care, incorporating technological advances and scientific foundations from different knowledge areas that offer new perspectives and new spaces to prepare health professionals, and also turns the study of contents in the course subject Nursing Service Management more significant and attractive.

In view of the above, the following research question emerged: Can the use of the WebQuest method favor the learning process of contents regarding "Material Resource Management in Nursing", offered in the course subject Nursing Service Management?

This paper aimed to describe the assessment of a WebQuest on the theme "material resource management in nursing" by undergraduate students.

\section{Method}

An exploratory, descriptive and qualitative research was carried out to observe, describe and express dimensions of a research object( ${ }^{(7)}$ through the development and practice of a virtual learning environment, using the WebQuest method in three phases: planning, development and practice. Phase 1 comprised the pedagogical aspect of content elaboration and definition according to the steps proposed by the WebQuest method. Phase 2 involved content organization, inclusion of images and completion of the WebQuest. Phase 3 corresponded to making the WebQuest available on the educational platform, putting it in practice and having students assess it.

The study was carried out at a private teaching institution in the interior of São Paulo state, in the second semester of 2008. The sample contained 23 students, divided in small groups that attended to the following inclusion criteria: the student needs to be regularly 
enrolled in the eighth semester, have attended curricular activities and completed the semester's theoretical and practical assessment activities; the student should have participated in all steps of the activities involved in the research; the student should have signed the Free and Informed Consent Term; and exclusion criteria: not having completed the assessment activities of the course subjects taken during the semester; having shown interest in not participating in the research or desire to interrupt their participation in any of the phases.

Approval for the project was obtained from the Research Ethics Committee at the University of São Paulo at Ribeirão Preto College of Nursing (Protocol 0978/2008), according to Decree $196 / 96$ on the observation of ethical aspects for research involving human beings.

Didactical-pedagogical activities were made available for all interested studies, but their participation as a research subject was characterized as from the conclusion of all phases and agreement to perform the assessment of the WebQuest method.

Participation in the Assessment of the adopted method only occurred after the end of the assessment period and availability of the semester grades, with a view to guaranteeing the possibility of exerting the free power to choose and not impair the voluntary nature of the students' decision.

For practice, the WebQuest was made available on the educational platform of the teaching institution where the study was carried out, permitting access to Internet tools. All students regularly enrolled in the course subject Supervised Curricular Training II performed the activities.

During four days, the students took part in the proposed activities, with three class periods dedicated to the development of the WebQuest and one to the Assessment, on previously set days and times, each period with an average three-hour duration, compatible with course times, using available computer laboratories at the institution.

The Assessment section was developed by consulting rubrics published on the web, indicated by specialized WebQuest creation sites and presented to the students after the presentation of the Task, before starting the Process section(8).

At the end of phase 3, the Assessment included two phases, one in which the students assessed the developed proposal and another with their selfassessment and that of the work group. The first phase comprised questions on the adopted method and the virtual learning environment. In the second, questions addressed the student's individual performance and that of the group responsible for performing the task, scoring based on a scale with the variables: unsatisfactory (1), reasonable (2), satisfactory (3) and excellent (4). The students were asked to descriptively present the motives for unsatisfactory or reasonable assessments at the end of each Assessment phase.

In the scale, each category was presented in onedimensional continua, that is, a continuum separated into numerical units and which can be applied to measure a certain property of an object. To measure intangible things like attitudes, beliefs and values, a numerical scale should be constructed that can subjectively measure the extent to which something is present ${ }^{(9)}$.

In Phase 1 of the Assessment, categories of indicators are presented in a simple and objective way, related to the development of specific skills for the judicious analysis of resources available on the Internet to support the accomplishment of each task suggested in the WebQuest: (1.1) Did the information permit the development of the proposal? (1.2) Was the information presented in a clear way? (1.3) Is the presentation esthetically attractive and used effectively in content transmission? (1.4) Did the sites attend to the information needs regarding the study theme? (1.5) Do you consider the sites as reliable information sources? (1.6) Does the information on the sites seem to be coherent with what you know about the subject?

In Phase II of the Assessment, scores and concepts are presented related to the student's and the group's attitudes while accomplishing the tasks. The criteria were defined based on aspects that need to be valued in the permanent assessment of professional performance by nurses themselves, as well as in the assessment of their work group, inherent in Nursing human resource management.

The first criterion (2.1) refers to the participation in reading activities: fully participated in reading activities (excellent $=4$ ); participated little in reading (satisfactory $=3$ ); did not participate actively in reading (reasonable $=2$ ); did not participate in reading activities (unsatisfactory=1).

The second criterion (2.2) refers to the assessment of the answers elaborated by the students: answers the questions clearly, writes in full sentences without grammatical errors, shows creativity and originality (excellent=4); answers questions, writes with small grammatical and sentence structure errors, but they do not interfere in readability and shows some creativity 
(satisfactory $=3$ ); did not answer all questions, with many grammatical errors and little originality (reasonable=2); did not answer the questions, many errors and little readability (unsatisfactory $=1$ ).

The third criterion (2.3) refers to assessing the completion of the proposed frames: they are filled out correctly and relevant for the work (excellent $=4$ ); they are filled out with few errors, good appearance and relevance for the work (satisfactory $=3$ ); they are filled out wrongly or not filled out, the visual aspect is not tasteful, but quite relevant for the work (reasonable $=2$ ); they are incomplete, filled out wrongly, and with a lack of relevance for the work (unsatisfactory $=1$ ).

The fourth criterion (2.4) refers to assessing the completion of worksheets: they are filled out correctly (excellent $=4$ ); they are not totally concluded, but most of the work is done (satisfactory=3); they are incomplete, but an attempt was made (reasonable=2); they are incomplete and hardly any attempt was made (unsatisfactory=1).

The fifth criterion (2.5) refers to the assessment of the work group: the group worked together for reading, research and daily work (excellent $=4$ ); the group worked together while reading some texts, in the research and project elaboration (satisfactory $=3$ ); the group did not function well together, but some members concluded the work (reasonable $=2$ ); the group did not dedicate itself to the work at all times or worked unsatisfactorily (unsatisfactory=1).

The student sent the Assessment by accessing the Student Area on the teaching institution's educational platform, commonly used in the programmed activities. After concluding the process, the student received the confirmation of successful submission and the researcher gained access to the material on the educational platform.

Each group received an identification number (1 to 8) with a view to guaranteeing the ethical principle of confidentiality.

\section{Results}

The students' considerations on Phase I of the Assessment section are in line with the proposals and intended objectives, as well as the observations made during the activities. The students were asked to comment on the aspects that were considered reasonable and unsatisfactory, but they described considerations that should be presented.
I did not find unsatisfactory aspects, but only the printing of one of the texts was very small. (Part I - Student 1 - Group 1)

Regarding the transitions between one slide and another, a lot of time is lost to change them. So the suggestion would be less slides and, consequently, less animation, so as not to tire the student, thus resulting in the quality of the work. (Part I Student 10 - Group 3b)

Some information on wound treatment with necrosis tissue did not offer options of more accessible and feasible products for treatment: for example $10 \%$ papain. (Part I - Student 18 - Group 7)

If there were more time, or the previous reading of the texts, the work could have been accomplished with less doubts and more security. But it was a very rich experience. (Part I Student 23 - Group 8)

The work was satisfactory but tiresome, due to the little time available to accomplish it, I believe that, if we had more time, we could have discussed more. (Part I - Student 15 Group 5)

The work was elaborated in a clear, objective and attractive form, permitting easy visualization of the proposal. (Part I Student 9 - Group 3b)

Regarding this new form of teaching, it is something extremely valuable and offers students better learning, stimulating them to search and actually be part of this learning, in which both students and teachers end up learning. In other words, students move from passive to active beings in their learning process. Of course, like any learning form, it has advantages and disadvantages and what $I$ can mention as a disadvantage is that the student is stuck with information from the Internet and this permits some errors, so students should also be prepared for this. What I also have to say is that, really, this form has every condition to turn into a success, provided that the institution has trained people for this purpose and offers students the possibilities to explore the new technologies. (Part I - Student 11 - Group 4)

Regarding the scoring of the assessed categories, excellent (score 4) and satisfactory (score 3) considerations predominated in all criteria, and two manifestations considered reasonable (score 2), one regarding the presentation of the proposal (criterion 1.3) and another on the information made available through the sites (criterion 1.4).

The students' manifestations about Phase II of the Assessment section refer to the description of situations that impaired teamwork and to consensual decision, as described below: 
Although the Group contains members that stand out individually, it did not manage to do a good job as a team, a lot of dispersion occurred and loss of focus in the work. (Part II Student 18 - Group 7)

During the proposed work, the group got along really well at first, but then there was a relapse, as only one wanted to do the work and did not accept the other group members' opinions either. (Part II - Student 19 - Group 7)

The group comprised 04 people who divided into 2 subgroups of 02 people, so that the group did not work together. (Part II - Student 9 - Group 3b)

The students' manifestations reveal the acknowledgement that the group members' individual characteristics do not guarantee consensual decision and successful teamwork. It also evidences the valuation of dialogue for the group work process, allied with the acknowledgement of subdivisions as harmful to group integration as a whole and to a shared vision.

With regard to the scoring of the categories assessed in Phase II of the Assessment section, excellent (score 4) and satisfactory (score 3) predominated for all criteria. The three reasonable (score 2 ) manifestations refer to the group assessment (criterion 2.5).

Based on the described assessments, it was verified that eight students $(1,9,10,11,14,18,19$ and 23) presented their manifestations and that two students ( 9 and 18) discussed the two Phases of the Assessment section. Regarding the phases, six opinions referred to Phase I and four to Phase II of the Assessment.

For three groups $(2,6$ and $3 a)$, the assessment remained restricted to the scoring of the established criteria, without any text report.

\section{Discussion}

The Assessment section, the only activity planned for the final day of the proposed practice, cannot be considered the end. This assertion reflects the main finding after the end of activities.

As expressed earlier, the criteria considered in the Assessment section were presented before the start of the tasks. The focus on the evolution of the implementation phase served as a stimulus for the students' selfassessment of how they conducted their own learning and, consequently, professional education.

Thus, betting on self-regulation in the strictest sense means reinforcing the subject's abilities to manage his/ her own projects, strategies adopted in view of tasks and obstacles, in other words, any educative action can only stimulate a subject's self-development, self-learning, self-regulation, modifying his/her means, interacting with that means ${ }^{(10)}$.

Didactics oriented at the regulation of learning processes does not put great hope in massive remediation, that is, it invests more in interactive regulation based on an observation and intervention in a situation. When the task is not finished, the teacher takes the risk of interfering in ongoing thinking and communication processes ${ }^{(10)}$.

The use of computer technologies permits the accomplishment of more creative processes, offering nursing graduation students the opportunity of more active learning(11).

Moreover, the use of knowledge made available on the Internet can be considered auxiliary in the teachinglearning process for future professionals' skills and competency development, mainly in nursing(12).

The aspects the students appointed confirm the importance of assessment in a research or in the teaching-learning process with a view to identifying elements that permit diagnosing difficulties or facilities to achieve integration between educational product and student on the learning route. Despite the described difficulties, the assessment confirms that graduation students are open to the use of communication and information technologies as a means to get access to information and learning(12).

Thus, the isolated analysis of the scores immediately requires association with different assessment times the teacher held during the proposal with a view to a better understanding of the learning process.

In the use of WebQuest, the teacher is responsible for mediating the experience. The teacher's presence is needed to orient the work and verify whether the research process is being conducted adequately. When observing the students, the teacher should attempt to understand how the teaching-learning process takes place, what are the difficulties and the best strategies to support the process, clarifying doubts, giving advice on data recording and mediating discussions(2).

Assessment turns into a pedagogical tool to continue, reorient, correct and stimulate self-learning when a model proposes knowledge construction, contextualization, re-signification, application in one's own reality, stimulation of imagination and discovery. A production understood in this way constitutes the essence of self-learning, especially in view of the possibility of products obtained through work groups, that is, the effort of shared learning ${ }^{(6)}$.

The main finding was that Assessment plays its role better when it intends to offer opportunities of 
gradual approximation, according to the specificities inherent in the teaching-learning process and which cannot be generalized. In this sense, the most valuable skill discerned in the assessment process refers to the manifestation of the students' personal impressions on the developed proposal, available resources and the work group.

Offering space for formative assessment requires assuming a renunciation by considering that all participants are equally distant from the objective. On the opposite, one should depart from each person's effective knowledge, the resources one manages to mobilize to invest in the road ahead, the obstacles that need to be overcome and adherence to the education project, with a view to permitting a distinguished attribution to adequate didactical situations ${ }^{(10)}$.

Regarding the contents of the assessments, in Phase I, negative considerations refer to the font size, number of slides and animations, transition between screens, limited information range in the available texts, reading restricted to materials available on the Internet and little time for discussions and reading.

Positive considerations refer to the presentation of the proposal, that is, clarity, objectiveness, good visualization, attractive form, and are also related to the method as a rich experience that stimulates active participation in the learning process.

The aspects the students appointed, such as: little time for reading and discussions; considerations on the need for sites that offer further information: request for print sources for research, allied with the acknowledgement of the need for technical-scientific knowledge and professional training, demonstrate that, despite the need for review, the proposal reached the initial intention to arouse students' interest in research, in combination with the acknowledgement of the need to learn more, and to keep oneself updated in order to be apt and trained for Nursing work.

In this sense, the students' considerations permit affirming that the assessments represent a valuable opportunity to modify important aspects with a view to the future availability of the WebQuest, considering the possibilities in terms of refinements for continuous improvement and contribution to the nursing learning process $^{(13)}$.

In Phase II of the Assessment section, the analysis of the students' comments recalls that a shared vision is not an idea, but a stimulating force, sufficient to obtain support from more than one person, but ceases being an abstraction and gains form when people develop a sense of communication that provides coherence to different activities and enhances the mutual commitment to maintain this vision, not only individually, but as a group $^{(14)}$.

In this sense, team learning involves dialogical practice, which allows teams to share a new language in order to describe and deal with the complexity, a "collective" language, as team learning is limited without a shared language to treat complexity ${ }^{(14)}$.

The assertions the author presented relate to fundamental aspects the students described in the group assessment, during the development of the proposed activities, but also refer to the reality nurses experience in health services, marked by the difficulties inherent in the contradictions and tensions of human relations.

\section{Final considerations}

The development and practice of the WebQuest method permits confirming the importance of innovative educative practices centered on permanent assessment and self-assessment of students' learning in situations that intend to simulate the solution of concrete problems experiences in daily nursing work, especially directed at competency and skills development.

Formative assessment is recognized as a consequence of an educative project that is closely related with the pedagogical and thematic treatment, inserted and disclosed during the entire teachinglearning process, with a focus on active participation and co-responsibility through self-learning.

Finally, experience reinforces the importance of informatics and information technologies as an instrument for a mediating teaching practice in the integration between valid knowledge and the complex and dynamic reality of health services, with a view to its transformation to achieve Nursing care quality.

\section{References}

1. Webquest.org [internet]. San Diego State University. Dodge B. What is a WebQuest? [acesso em: 24 out 2008]. Disponível em: http://webquest.org/index.php.

2. Abar CAAP, Barbosa LM. WebQuest: um desafio para o professor. São Paulo (SP): Avercamp; 2008.
3. Senac Webquest [internet]. São Paulo. O que é. [acesso em: 25 out 2008]. Disponível em: http://webquest.sp.senac.br/ textos/oque. 
4. Aprendente [internet]. Barato JN. Avaliação em WebQuest: Avaliação autêntica. [acesso em: 06 jun 2009]. Disponível em: http://aprendente.blogspot.com/2005/04/avaliao-emwebquests.html.

5. Teacher Vision [internet]. The Advantages of Rubrics: part one in a five parts series. [acesso em: 06 jun 2009] Disponível em: http://www.teachervision.fen.com/teaching-methods-andmanagement/rubrics/4522.html.

6. Pérez FG, Castilho DP. Apuentes para uma educación a distancia alternativa. Buenos Aires (ARG): La Crujía; 2007.

7. Seltriz C, Wrightsman LS, Cook SW, Kidder LH. Métodos de pesquisa nas relações sociais. São Paulo (SP): EPU; 1987.

8. Webquest.org [internet]. San Diego State University. Dodge B. Creating WebQuests. [acesso 24 out 2008]. Disponível em: http://webquest.org/index-create.php.

9. Richardson RJ. Pesquisa Social: métodos e técnicas. $3^{a}$ ed. São Paulo (SP): Atlas; 1999.
10. Perrenoud P. Avaliação: da excelência à regulação das aprendizagens entre duas lógicas. Porto Alegre (RS): Artes Médicas Sul; 1999.

11. Cogo ALP, Pedro ENR, Silveira DT, Silva APSS, Alves RHK, Catalan VM. Desenvolvimento e utilização de objetos educacionais digitais no ensino de enfermagem. Rev. LatinoAm. Enfermagem [internet]. jul/ago 2007 [acesso em: $15 \mathrm{dez}$ 2009]; 15(4). Disponível em: http://www.scielo.br/pdf/rlae/ v15n4/pt_v15n4a28.pdf.

12. Aguiar RV, Cassiani SHDB. Desenvolvimento e avaliação de ambiente virtual de aprendizagem em curso profissionalizante de enfermagem. Rev. Latino-Am. Enfermagem [internet]. nov/ dez 2006 [acesso em: 15 dez 2009]; 15 (6). Disponível em: http://www.scielo.br/pdf/rlae/v15n6/pt_04.pdf.

13. Zem-Mascarenhas SH, Cassiani SHDB. Desenvolvimento e avaliação de um software educacional para o ensino de enfermagem pediátrica. Rev. Latino-Am. Enfermagem [internet]. nov/dez 2001 [acesso em: 15 dez 2009]; 9 (6). Disponível em: http://www.scielo.br/pdf/rlae/v9n6/7820.pdf.

14. Senge PM. A quinta disciplina: arte e prática da organização que aprende. São Paulo (SP): Círculo do Livro; 1998. 